\title{
AMANAH AGUNG TUHAN YESUS DALAM KEEMPAT INJIL DAN IMPLIKASINYA DALAM MEMAHAMI INJIL, BUDAYA DAN PEWARTA INJIL
}

\author{
Gregorius TriWardoyo* \\ Program Studi Ilmu Filsafat, Fakultas Filsafat Keilahian, \\ Sekolah Tinggi Filsafat Teologi Widya Sasana Malang \\ Email: gtricm@gmail.com
}

\begin{abstract}
Abstrak
Injil Matius 28:16-20 kerap kali dijadikan dasar misi murid-murid Yesus di dunia ini. Ada bahaya misi disempitkan pada tindakan membaptis saja. Melalui studi intertekstual yakni dengan membandingkan Injil Matius dengan ketiga Injil lainnya, ditemukan bahwa misi tidak sekadar tindakan membaptis tetapi lebih-lebih mewartakan Injil yang berisi bahwa Allah senantiasa menyertai umat manusia dan bahwa Allah yang sama menawarkan kepada umat manusia pertobatan dan pengampunan dosa dari Allah. Inilah kabar sukacita yang hendaknya diwartakan oleh pewarta Injil dalam budaya dimana mereka hidup.
\end{abstract}

Kata-kata kunci: Injil, budaya, pewarta Injil, pertobatan, dan pengampunan dosa.

\section{Pengantar}

Perutusan atau misi Gereja Katolik pada umumnya didasarkan pada Injil Matius 28:16-20. Dalam perikop singkat ini, Yesus mengutus para muridNya untuk pergi dan menjadikan semua bangsa muridNya dan untuk membaptis mereka dalam nama Bapa dan Anak dan Roh Kudus (bdk. Mat. 28:19). Pertanyaannya ialah bagaimana amanah agung ini harus dilaksanakan oleh para misionaris? Apa yang dimaksud semua bangsa di sini? Apakah kita wajib membaptis mereka? Mengapa "Ya" dan mengapa "Tidak"?

Berangkat dari pertanyaan-pertanyaan di atas, kita akan mencoba mendalami amanah Yesus dalam Injil Matius di atas sambil membandingkan dengan paralelnya, yakni dengan Injil Markus, Lukas,

\footnotetext{
* Gregorius Tri Wardoyo, Lisensiat Kitab Suci dari Pontificum Institutum Biblicum dan doktor Teologi Kitab Suci di Universitas St. Thomas Aquinas, Angelicum. Keduanya berada di kota Roma, Italia; dosen Kitab Suci di STFT Widya Sasana Malang.
} 
dan Yohanes. Harapannya ialah kita semakin memahami makna amanah Yesus kepada para muridNya dalam konteks pesan Injil secara keseluruhan dan akhirnya mampu mewartakannya kepada bangsa-bangsa yang berbeda budaya dengan para misionaris dimana mereka diutus.

\section{Amanah Yesus dalam keempat Injil}

Pembaca yang jeli akan menemukan perbedaan dari masingmasing perikop yang berbicara mengenai perutusan Yesus kepada para muridNya. Di bawah ini, kita akan melihat masing-masing perikop dengan menunjukkan penekanannya.

\section{a. Matius 28:16-20: "Membaptis Semua Bangsa"}

Penginjil Matius menempatkan amanah terakhir Yesus dalam konteks kebangkitan Kristus. Ini artinya, kebangkitan Kristus menjadi titik tolak perutusan para murid. Perutusan para murid bersumber dan memiliki akarnya pada Kristus yang telah bangkit. Kristus yang bangkit kini memiliki kuasa atas sorga dan bumi. Dengan kuasa yang Ia miliki, Ia mempunyai otoritas untuk ganti mengutus para muridNya.

Ada tiga perutusan yang dipercayakan kepada murid-muridNya, yaitu 1) menjadikan semua bangsa muridNya, 2) membaptis mereka, dan 3) mengajar mereka segala perintahNya. Yang menarik dalam

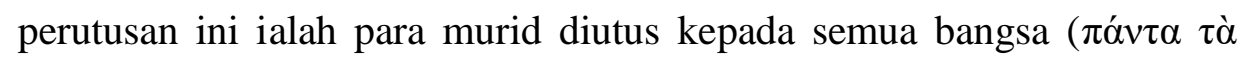
$\check{\varepsilon} \theta v \eta)$. Istilah bangsa secara umum menunjuk pada kaum pagan, yakni orang-orang yang belum mengenal Allah (bdk. Mat. 6:32).

Di tempat lain, dalam Injil Matius penggunaan "semua bangsa" ditemukan pada Mat. 25:32 dalam konteks pengadilan terakhir. Dalam perikop ini, mereka dipisah menjadi dua. Yang satu di sebelah kanan raja dan disebut "domba". Satunya berada di sebelah kiri raja, dan disebut "kambing". Dari kisah pengadilan terakhir ini, ada kesan kuat bahwa mereka yang disebut "semua bangsa" ini tidak mengenal Kristus dalam hidup mereka. Akan tetapi, mereka yang dimasukkan dalam golongan "domba" rupanya diperkenankan untuk menerima warisan sorgawi, yaitu Kerajaan (bdk. Mat. 25:34). 
Dari perumpamaan di atas, diketahui bahwa keselamatan yang dianugerahkan kepada mereka, yang tidak atau belum mengenal Kristus, pertama-tama karena perbuatan baik mereka terhadap orangorang yang dianggap paling hina. Orang paling hina, dalam konteks ini, ialah representasi kehadiran Kristus. Kalau mereka diselamatkan dengan cara ini, apakah mereka perlu dibaptis supaya memperoleh keselamatan? Lantas apa arti pentingnya baptis bagi mereka?

Selain itu, kabar gembira yang patut disyukuri dan dirayakan oleh para murid ialah bahwa Yesus Kristus akan menyertai para murid sampai kepada akhir zaman (bdk. Mat. 28:20). Janji Yesus ini menegaskan kembali apa yang telah dijanjikan Allah untuk menyertai umat manusia (Imanuel) pada awal Injil Matius (1:22-23).

\section{b. Markus 16:14-18: "Pergi ke Seluruh Makhluk dan Seluruh Dunia"}

Penginjil Markus dengan jelas mengisahkan peristiwa Yesus terangkat ke sorga, setelah Ia memberikan amanahNya yang terakhir kepada para murid. Kini, Yesus duduk di sebelah kanan Allah. Akan tetapi, dilaporkan bahwa Ia tetap ikut bekerja bersama para muridNya. Kehadiran Yesus ditampakkan dengan tanda-tanda atau mukjizat yang menyertai para muridNya.

Berbeda dengan Injil Matius, di sini kepada para murid dipercayakan perutusan untuk: 1) pergi ke seluruh dunia, dan 2) memberitakan Injil kepada seluruh makhluk. "Seluruh dunia" dan "seluruh makhluk" kiranya bisa kita lihat sebagai paralel yang mana keduanya mengandung makna yang kurang lebih sama. Apakah dengan demikian, perutusan para murid mencakup tidak hanya "semua bangsa" tetapi juga mereka yang sudah menerima dan mengakui Yesus sebagai Allah?

Lepas dari persoalan di atas, perbedaan menonjol antara Injil Markus dan Matius ialah terletak pada isi amanah Yesus. Di dalam Injil Matius, para murid diminta untuk membaptis semua bangsa menjadi muridNya, sementara di dalam Injil Markus, para murid diutus untuk mewartakan Injil kepada seluruh makhluk. Apakah Injil bisa kita artikan dengan tindakan membaptis? Atau apakah Injil yang dimaksudkan oleh 
Markus bisa kita kaitkan dengan janji Allah untuk menyertai kita (Imanuel)? Mengenai persoalan ini, kita akan mendalaminya di bagian bawah makalah ini.

\section{c. Lukas 24:44-49: "Pertobatan dan Pengampunan Dosa"}

Penginjil Lukas membingkai perutusan Yesus kepada para muridnya dalam bentuk kalimat indikatif, bukan imperatif sebagaimana digunakan oleh kedua penginjil sebelumnya. Dalam Luk. 24:47 dikatakan, "Dan lagi: dalam nama-Nya berita tentang pertobatan dan pengampunan dosa harus disampaikan kepada segala bangsa, mulai dari Yerusalem." Alih-alih membaptis semua bangsa atau mewartakan Injil kepada seluruh makhluk, penginjil Lukas lebih memilih untuk menekankan unsur pertobatan dan pengampunan dosa sebagai isi dari misi para murid Yesus.

Kalau kita memperhitungkan kemunculan ungkapan "bertobat" dalam Injil Lukas sebanyak delapan kali; Lukas menggunakan ungkapan ini lebih banyak dibanding Injil Matius dan Markus yang hanya muncul masing-masing sebanyak lima kali dan satu kali saja. Ini mau mengatakan bahwa bagi penginjil Lukas, pertobatan merupakan isi penting dari pesan yang hendak disampaikan oleh Injilnya. Melalui Yohanes Pembaptis, penginjil Lukas sudah sejak dari awal Injilnya memproklamasikan seruan berikut ini, "Bertobatlah dan berilah dirimu dibaptis dan Allah akan mengampuni dosamu" (Luk. 3:3; bdk. Mrk. 1:4). Dan inilah yang kemudian diulang kembali di dalam perutusan Yesus kepada para muridNya sebagaimana dilaporkan oleh Luk. 24.

Selain isi, penginjil Lukas juga ingin menekankan peran para murid sebagai saksi Kristus. Saksi, di sini, hasil terjemahan dari bahasa aslinya, yakni martir. Menurut Kitab Imamat (5:1), saksi ialah orang yang melihat atau mengetahui suatu peristiwa yang terjadi. Dengan demikian, sah tidaknya seseorang diangkat menjadi saksi ialah bila orang tersebut benar-benar melihat dengan mata kepalanya sendiri. Dalam konteks Injil Lukas 24, arti saksi Kristus kiranya lebih pas kalau kita baca dalam terang Kis.10:39 yang mengatakan, "Dan kami adalah saksi dari segala sesuatu yang diperbuat-Nya di tanah Yudea maupun di Yerusalem; dan 
mereka telah membunuh Dia dan menggantung Dia pada kayu salib." Untuk inilah, kriteria yang digunakan oleh para rasul untuk mencari pengganti Yudas Iskariot haruslah orang yang senantiasa ada berada dengan para rasul dan Yesus, terutama mulai dari pembaptisan Yohanes sampai pada saat Yesus diangkat ke sorga (bdk. Kis. 1:21-22).

Pertanyaan yang segera muncul ialah bagaimana dengan kita yang tidak hidup bersama- sama Yesus secara fisik? Apakah kita bisa menjadi saksi? Iman yang dianugerahkan kepada kita apakah cukup dijadikan dasar untuk menjadi saksi Kristus? Dalam Injil keempat dikatakan, "Berbahagialah mereka yang tidak melihat, namun percaya" (Yoh. 20:29). Iman kita kepada Yesus bukan pertama-tama buah dari penglihatan, melainkan buah dari pendengaran.

Berkat mendengar, dengan demikian, kita dimasukkan dalam golongan orang-orang yang percaya kepada Yesus. Kita, yang sudah percaya kepada Kristus, dipanggil untuk menjadi saksiNya di dunia ini. Pada akhirnya, seperti dikatakan Petrus, "Sekalipun kamu belum pernah melihat Dia, namun kamu mengasihiNya. Kamu percaya kepada Dia, sekalipun sekarang tidak melihatNya. Kamu bergembira karena sukacita yang mulia dan yang tidak terkatakan, karena kamu telah mencapai tujuan imanmu, yaitu keselamatan jiwamu" (1Ptr. 1:8-9).

\section{d. Yohanes 20:19-23: "Pengampunan Dosa"}

Perutusan Yesus kepada para muridNya mengambil konteks tatkala Yesus menampakkan diri kepada murid-muridNya, kecuali kepada Tomas, saat mereka sedang berkumpul bersama. Dilaporkan bahwa para murid dalam situasi dan kondisi ketakutan kepada orangorang Yahudi. Dari konteks ini, kehadiran Yesus di tengah-tengah mereka bertujuan untuk menghibur dan menguatkan para muridNya. Tindakan Yesus menghembusi mereka sambil berkata, "Terimalah Roh Kudus" merupakan indikasi jelas bahwa Yesus hadir untuk menguatkan mereka dan untuk memperbaharui mereka sebagai ciptaan baru (bdk. Kej. 2:7).

Pencurahan Roh Kudus atas para muridNya juga memampukan para murid untuk melaksanakan perutusan mereka. Menarik 
memerhatikan di sini, perutusan Yesus kepada para muridNya terkait erat dengan tindakan pengampunan dosa. Dengan demikian, Injil Yohanes dan Lukas memiliki isi yang kurang lebih sama berkaitan dengan perutusan para murid, yaitu pentingnya pengampunan dosa. Kuasa pengampunan dosa kini tidak hanya menjadi wewenang Allah (bdk. Luk. 5:21, 24), tetapi oleh Yesus wewenang ini juga dipercayakan kepada para muridNya. Konkretnya, kuasa mengampuni dosa ini nampak pada kuasa yang dimiliki oleh para imam yang dinyatakan dalam sakramen rekonsiliasi.

Sejauh ini, kita sudah melihat amanah Yesus di keempat Injil. Masing-masing penginjil mempunyai penekanan sendiri di dalam memformulasikan amanah Guru mereka. Hanya Matius yang menekankan perintah untuk membaptis semua bangsa, sedangkan ketiga penginjil lainnya lebih menekankan pentingnya pewartaan Injil dan pengampunan dosa. Berangkat dari analisis kita di atas, sekarang kita akan mencoba untuk menarik implikasi teologis dari amanah Yesus bagi kita yang hidup di zaman ini. Ada tiga tema yang bisa kita tarik dari analisis di atas: Injil, budaya, dan pewarta Injil. Di bawah ini, kita akan membahas satu demi satu.

\section{Injil: Imanuel dan Pengampunan Dosa}

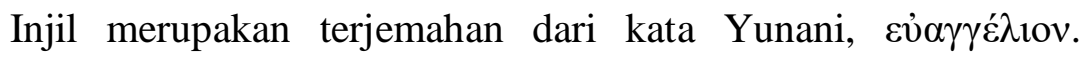
Selain diterjemahkan sebagai Injil, kata ini juga memiliki arti "kabar baik". Pada umumnya, kata ini bisa mengacu pada tindakan pengajaran Injil (bdk. 1Kor. 4:15); atau pada tindakan evangelisasi, penyebaran Injil (bdk. Flp. 4:3); atau juga bisa mengacu pada isi atau pesan keselamatan (bdk. 1Kor. 9:14). Memerhatikan konsep-konsep ini, Injil masih dirasakan sebagai konsep yang abstrak. Jika Injil itu dimengerti sebagai kabar baik, kita bisa bertanya, apa itu kabar baik? Bagi siapakah kabar baik itu?

Injil sendiri kerap dimengerti dan dibatasi sebagai keempat buku pertama dalam PB saja. Keempat Injil yang dimaksud ialah Matius, Markus, Lukas dan Yohanes. Pembatasan hanya pada empat tulisan ini berkaitan erat dengan isinya. Isi keempat Injil ialah kisah mengenai Yesus-hidup, sengsara, dan kebangkitanNya. Akan tetapi mereka 
memiliki penekanan yang berbeda-beda dalam melukiskan figur Yesus. Matius menekankan Yesus sebagai Raja dan Mesias; Markus lebih melihat Yesus sebagai Raja dan sekaligus Hamba; bagi Lukas Yesus adalah Anak Allah yang mahatinggi; sedangkan Yohanes lebih menekankan keilahian dan regalitas Yesus-Yesus sebagai Raja. Injil, dengan demikian, bisa kita mengerti sebagai Yesus sendiri. Yesuslah kabar baik itu.

Dari amanah Yesus dalam keempat Injil di atas, kita bisa menyimpulkan isi kabar baik atau Injil. Kabar baik pertama ialah Allah, melalui Putera tunggalNya, senantiasa menyertai kita (Imanuel). Bahwa Allah selalu menyertai umatNya sudah dialami oleh umat Perjanjian Lama, yaitu bangsa Israel, selaku bangsa pilihan. Penyertaan Allah dalam kehidupan umat Israel dirasakan dan dialami tidak hanya pada saat mereka berada di kampung halaman sendiri, tetapi juga tatkala mereka berada di Mesir dan di Babel. Ini artinya, Allah tidak pernah meninggalkan umatNya. Dalam Perjanjian Baru, janji Allah untuk menyertai umatNya nyata di dalam diri PuteraNya yang menjelma menjadi manusia. Kabar baik kedua ialah Allah selalu menawarkan kesempatan bagi umatNya untuk bertobat dan merasakan pengampunan. Tema pertobatan dan pengampunan bukanlah hal baru di dalam Perjanjian Baru. Sudah sejak manusia pertama jatuh ke dalam godaan si ular, Allah terus menerus menawarkan dan mengajak umatNya untuk bertobat. Ajakan untuk bertobat dari pihak Allah dilakukan secara intens oleh para nabi. Perjanjian Lama sebenarnya bisa dibaca dengan skema pertobatan dan pengampunan. Perjanjian Lama mengisahkan perjalanan umat Israel, jatuh bangun mereka di dalam menanggapi kasih Allah. Kalau kita cermat dalam membaca Perjanjian Lama, maka kita akan melihat dinamika umat: berdosa-bertobat-pengampunan kemudian berdosa- bertobat-pengampunan, dst.

Rupanya para Nabi tidak berhasil untuk mengajak umat bertobat, maka Bapa mengutus Putera tunggalNya, Yesus. Perutusan Yesus merupakan bukti bahwa Allah mengasihi umatNya (bdk. 1Yoh. 4:9). Misi Yesus jelas yaitu "Untuk menyampaikan kabar baik kepada orang-orang miskin; untuk memberitakan pembebasan kepada orangorang tawanan, dan penglihatan bagi orang-orang buta, untuk 
membebaskan orang-orang yang tertindas, untuk memberitakan tahun rahmat Tuhan telah datang" (bdk. Luk. 4:18-19).

Lebih jauh lagi, misi Yesus ialah untuk memulihkan kemanusiaan kita yang telah rusak akibat dosa pertama. Untuk itu, sejak awal misiNya, Yesus menyerukan pentingnya pertobatan karena Kerajaan Sorga telah dekat (bdk. Mat. 4:17). Kemampuan manusia untuk menanggapi seruan Yesus tersebut kerap terhalang oleh manusia itu sendiri yang hidupnya kerap terbelenggu oleh dosa. Oleh karena itu, di dalam Lukas di atas Yesus memproklamasikan perutusanNya bahwa Ia datang untuk membawa pembebasan. Orang-orang tawanan, buta, dan tertindas, sebagaimana digambarkan dalam perikop di atas, mencerminkan bahwa manusia masih terbelenggu oleh kuasa jahat sehingga ia tidak mampu secara bebas menjadi dirinya sendiri apalagi menanggapi kasih Allah.

Jadi, kabar baik yang menjadi isi dari Injil ialah kesediaan Allah untuk senantiasa menyertai umatNya (Imanuel) dan keselamatan yang ditawarkan kepada umat manusia melalui pertobatan dan pengampunan. Tentu kabar baik ini diperuntukkan bagi semua bangsa dan seluruh makhluk yang memiliki beraneka ragam budaya yang melatarbelakanginya. Untuk itu, di bawah ini kita akan membahas budaya sebagai konteks dimana Injil hendaknya diwartakan.

\section{Perjumpaan Injil dengan Budaya}

Ketiga Injil pertama secara eksplisit mengisahkan bahwa Yesus mengutus para muridNya untuk pergi ke semua bangsa, semua dunia, dan ke semua makhluk untuk mewartakan Injil. Ini berarti para murid, yang notabene adalah orang-orang Yahudi, harus masuk dan bersentuhan dengan budaya bangsa-bangsa lain. Berikut ini kita akan melihat misi dari beberapa murid Yesus, sebagai perwujudan amanah di atas. ${ }^{1}$

Petrus, yang bernama asli Simon, mendapatkan perutusan dari Yesus untuk pergi ke Roma. Ia mewartakan Injil di kota ini dan ia pun

\footnotetext{
${ }^{1}$ Pendalaman lebih lanjut tentang para rasul. Lih. Paus Benediktus XVI (terj. Emanuel P. D. Martasudjita, Pr.), The Apostles. Para Rasul. Asal-usul Gereja dan Para Teman Sekerja Mereka (Yogyakarta: Kanisius, 2015).
} 
meninggal di kota yang sama dengan cara disalib dengan kepala terbalik. Saat ini, makam Santo Petrus bisa kita temukan di bawah altar utama dari Basilika Santo Petrus, di Vatikan.

Setelah peristiwa pentakosta, Andreas melakukan misi untuk bangsa Yunani dan disebut sebagai rasul orang-orang Yunani. Menurut tradisi, Andreas meninggal di Patras dengan cara disiksa dan disalib seperti Petrus.

Berikutnya, ialah Rasul Yakobus Tua. Ia, menurut tradisi, pernah menjelajah dan mewartakan Injil ke Spanyol. Spanyol sendiri waktu itu masuk dalam wilayah kekaisaran Romawi. Menurut tradisi pula, Yakobus, kemungkinan besar meninggal di Spanyol dan jenazahnya di makamkan di sana, tepatnya di kota Santiago di Compostela. Saat ini, Yakobus sangat dihormati di Spanyol dengan banyaknya peziarah ke kota ini.

Selanjutnya, dilaporkan bahwa Yohanes melakukan pewartaan Injil di daerah Efesus. Ia meninggal di sana dalam usia yang sangat tua pada saat Kaisar Trayanus berkuasa. Kemudian pada abad VI, Kaisar Yustinianus membangun sebuah basilika yang besar untuk menghormati Yohanes. Basilika tersebut kini tinggal puing-puing. Di gereja Timur, Yohanes sangat terkenal dibanding di gereja Barat. Ikon yang dibuat menggambarkan Yohanes yang sangat tua dengan sikap kontemplatif yang sangat mendalam seakan-akan ingin mengajak kita untuk bersikap hening dan tenang.

Berdasarkan beberapa kisah, Filipus sendiri pergi mewartakan kabar baik ke daerah Yunani, tepatnya di Frigia dan Hierapolis. Di kota ini, Filipus meninggal dengan cara disiksa. Masih belum jelas, apakah ia disalib atau dirajam dengan batu.

Berkaitan dengan Tomas, menurut Origenes, ia pernah mewartakan Injil ke Siria dan Persia. Kemudian, Tomas pergi ke India Selatan. Kemungkinan besar ia pun meninggal di India. Sampai sekarang, Tomas mendapatkan tempat kehormatan di Gereja-gereja India.

Sama halnya dengan Tomas, tradisi juga mencatat kehadiran Bartolomeus di India. Bartolomeus meninggal dengan cara yang 
mengerikan yaitu dengan dikuliti tubuhnya. Mengenai lukisan Bartolomeus yang memegang kulitnya sendiri bisa ditemukan di kapel Sistina Vatikan; sebuah lukisan karya Michelangelo.

Terakhir, kita bisa menyebut Rasul Paulus, yang mendapat julukan rasul para bangsa. Dari antara para rasul yang kita sebutkan di atas kiranya Rasul Pauluslah yang banyak melakukan perjalanan misi. Untuk ini, kita bisa melihat peta di bagian akhir Kitab Suci kita. Di sana dilaporkan perjalanan misi Rasul Paulus, yang terbagi atas perjalanan misi pertama, kedua, dan ketiga dan ke Roma. Paulus meninggal sebagai martir di kota Roma. Ia dipenggal kepalanya dan menurut tradisi, ketika kepalanya dipenggal dan jatuh di tanah sebanyak tiga kali seketika itu juga keluarlah sumber air. Saat ini situs tempat Rasul Paulus dipenggal kepalanya bisa dijumpai di Roma, tepatnya di Tre Fontane.

Misi pada akhirnya menjadi ciri khas Gereja Katolik. Dibanding dengan gereja-gereja lain, tradisi misi dalam Gereja Katolik sangatlah kuat. Sebagai contohnya, kita akan mengambil dua orang santo yang (cukup) terkenal, yaitu Santo Fransiskus Xaverius, SJ., dan Santo Yohanes Gabriel, CM. Kedua santo ini, sebagaimana tercatat dalam sejarah Gereja, pernah singgah atau bahkan berkarya di Indonesia.

Fransiskus Xaverius lahir di Navarra, Spanyol pada tahun 1506 dan meninggal di Sancian, Tiongkok pada tahun $1552 .^{2}$ Ia berjanji untuk mengabdikan hidupnya demi pertobatan orang yang belum mengenal Kristus dan demi penyelamatan jiwa-jiwa. Untuk itu, setelah menjadi anggota Serikat Jesus, Fransiskus mendapat perutusan untuk bermisi di India, tepatnya di Goa pada tahun 1541. Ia tidak hanya berkarya di India tetapi juga di Sri Langka. Berkat kehadiran Fransiskus, banyak orang dipertobatkan dan memeluk agama Katolik.

Pada tahun 1545, Fransiskus singgah di Malaka selama tiga bulan sebelum berangkat ke Makasar. Waktu yang singkat ini ia gunakan untuk mengajar penduduk Malaka, dimana pada saat itu terjadi kemerosotan moral dan hidup perkawinan di sana akibat pengaruh dari kekayaan yang melimpah. Di sini pula, Fransiskus belajar bahasa

\footnotetext{
2 A. Heuken SJ, Ensiklopedi Orang Kudus. 1700 Nama Orang Kudus (Jakarta: Yayasan Cipta Loka Caraka, 2004), hlm. 123-126.
} 
Melayu sebagai salah satu bentuk persiapannya untuk bermisi di Indonesia.

Pada tahun 1546, ia melakukan pelayaran menuju ke Ambon. Selama dalam perjalanannya, ia banyak melakukan pelayanan bagi para pelaut dengan mendengarkan pengakuan dosa, mengunjungi orang sakit dan memberikan sakramen-sakramen termasuk berkotbah. Saat itu, di Ambon sudah ada umat yang beragama Kristen, kira-kira ada tujuh desa yang berpenduduk Kristen. Fransiskus sendiri selama di Ambon telah membaptis 1000 orang sambil mempersiapkan kedatangan imam-imam baru. Seusai misinya di Ambon, ia pergi menuju ke Ternate pada Juli 1646.

Kemudian, Fransiskus kembali ke Malaka untuk pergi bermisi ke Jepang. Setelah dua tahun bermisi di Jepang, ia pergi ke Tiongkok dan meninggal di sana, tepatnya di Sancian, karena sakit. Ia meninggal di usia yang sangat muda, sekitar 46 tahun.

Contoh berikutnya ialah Yohanes Gabriel Perboyre, CM., seorang misionaris dan martir di Cina. ${ }^{3}$ Bagi Yohanes Gabriel bermisi di Cina merupakan dambaan masa mudanya. Hal ini juga berlaku bagi para seminaris Perancis saat itu. Kemauan Yohanes Gabriel untuk bermisi di Cina dikobarkan oleh semangat menyelamatkan jiwa-jiwa (zelus animarum), salah satu keutamaan dalam CM.

Yohanes Gabriel lahir di Puech, Perancis, pada 6 Januari 1802. Setelah menerima tahbisan imam pada 23 September 1826, Yohanes tidak langsung berangkat ke tanah misi, Cina. Ia mendapat perutusan pertama sebagai pengajar di Seminari Saint Flour, milik keuskupan. Di sana, ia mengajar filsafat dan teologi. Baru pada tanggal 21 Maret 1835, Yohanes Gabriel berangkat bermisi ke Cina. Dengan menumpang kapal "Edmund", ia bersama ketujuh kawannya sempat melewati Batavia dan singgah di Surabaya, Jawa Timur. Dari suratnya diketahui bahwa ia sempat tinggal di Surabaya mulai 14 Juli sampai 10 Agustus 1835.

Selanjutnya, dicatat bahwa Yohanes Gabriel tiba di Macao dan tinggal di sana hingga akhir bulan Februari 1836. Ia tinggal di novisiat

\footnotetext{
${ }^{3}$ S. Ponticelli, CM.-Armadaya Riyanto, CM., Sahabat-sababat Tuban dan Orang Miskin, (Surabaya-Kediri: CM dan PK, 2002), hlm. 132-156.
} 
CM dengan lima belas novis, sambil belajar bahasa Cina dengan Romo Ly, imam CM asli Cina. Pada bulan Februari di tahun yang sama, ia berangkat ke Cina daratan dan memulai misinya di Nan-yang pada Agustus 1836. Karya misinya dijalani sebagaimana misi-misi pada umumnya, yaitu pelayanan misa, kunjungan orang sakit dan umat miskin, dan pengajaran agama.

Yang luar biasa dari Yohanes Gabriel ialah kematiaannya di usia 38 tahun sebagai martir. Ia praktis hanya berkarya di Cina selama 38 bulan saja. Ada kimiripan antara kematian Yohanes Gabriel dengan Yesus. Seperti Yesus, Yohanes ditangkap oleh tentara Cina karena dikhianati oleh umat demi 30 ons uang. Seperti Yesus, Yohanes mengalami siksa cambuk sebelum ia pun mati di kayu salib.

Contoh-contoh perutusan ke bangsa-bangsa lain di atas mau mengatakan bahwa perbedaan budaya bukanlah alasan untuk tidak mewartakan Injil. Dengan kata lain, perjumpaan Injil dan budaya tidak bisa dihindari. Perjumpaan Yesus dengan perempuan Samaria di sumur Yakub, di Sikhar, salah satu kota di Samaria, adalah contoh dari perjumpaan Injil (baca Yesus) dengan budaya bangsa lain, yakni Samaria (bdk. Yoh. 4:1-26). Berhadapan dengan bangsa asing, dialog menjadi salah satu kunci untuk masuk ke dalam budaya dan cara berpikir mereka. Contoh lain, ialah perutusan Petrus ke rumah Kornelius, orang bukan Yahudi, sebagaimana diceritakan dalam Kis. 10. Dari kedua contoh ini, Injil mau tidak mau harus berjumpa dengan budaya lain. Dengan sendirinya, langkah pertama yang harus diambil oleh para misionaris ialah belajar budaya mereka, salah satunya mempelajari bahasa dan adat istiadat mereka.

Yang terjadi pada para rasul pertama kemungkinan besar sama dengan apa yang terjadi dan dialami oleh para misionaris masa kini. Mereka harus belajar menguasai bahasa dari budaya setempat. Inilah inkulturasi yang pertama-tama harus dilakukan oleh misionaris. Franz van Lith, misionaris Belanda, ketika tiba di Indonesia pada tahun 1896, hal pertama yang ia lakukan ialah belajar bahasa Jawa termasuk budaya dan adatnya. 
Tuntutan untuk mempelajari bahasa asing ini kerap menjadi kendala utama bagi imam, suster, atau awam untuk pergi ke tanah misi. Tidak semua orang memiliki bakat untuk secara cepat mempelajari bahasa baru. Untuk ini, Santo Vinsensius, pendiri CM, meminta kepada para misionarisnya untuk memohon rahmat supaya kita bisa mempelajari bahasa asing dengan baik, sebagaimana dulu Allah juga mencurahkan karunia kepada para rasul untuk berbicara dalam aneka bahasa asing. Ini semua, menurut Vinsensius, demi kelanjutan misi para rasul dan demi pengajaran iman kepada semua orang. ${ }^{4}$ Maka, mempelajari dan menguasa bahasa dimana para misionaris diutus sangatlah penting.

Penguasaan bahasa setempat memungkinkan misionaris untuk membuka dialog dengan budaya yang lebih luas, yaitu adat atau kebiasaan mereka, termasuk dengan agama-agama yang sudah ada di tempat tersebut. Hal ini mengandaikan bahwa misionaris tidak datang ke tempat yang sama sekali tidak atau belum tersentuh oleh kebudayaan yang sudah ada sebelum-sebelumnya. Contoh untuk kasus ini bisa kita temukan dalam Kis. 17:15-34 yang menceritakan bagaimana Rasul Paulus meyakinkan warga Atena bahwa ada Allah yang hidup yang memiliki nama, bukan seperti allah yang mereka sembah.

Selanjutnya, di zaman sekarang, dialog tidak hanya terbatas pada dialog dengan kebudayaan lain termasuk kepercayaan yang sudah ada, tetapi juga dibuka kemungkinan untuk mengadakan dialog dengan kaum miskin, yang adalah bagian dari pelaku kebudayaan dari suatu bangsa. Khusus berkaitan dengan dialog dengan agama lain, kita hendaknya melakukan dengan penuh hormat dan menyadari bahwa dalam agama lain juga ada keselamatan (bdk. NA. 1). Meskipun begitu, kita tidak boleh berhenti mewartakan Kristus, yang adalah "jalan, kebenaran dan hidup" (bdk. Yoh. 14:6). Selanjutnya, dalam perjumpaan dengan agama lain, adalah kurang bijak apabila misionaris masuk dalam perdebatan dengan pemeluk agama-agama lain, terkait dengan hal-hal yang kontroversial. Perlu bagi misionaris untuk memiliki keutamaankeutamaan, seperti kesabaran, kerendahan hati, semangat berdoa, dan matiraga.

${ }^{4}$ SV. XII, 26-27, no. 183, 9 Juni 1658. 


\section{Pewarta Injil: “Tukang” Baptis atau Saksi Kristus?}

Analisis mengenai amanah agung Yesus di atas mengantar kita pada suatu kesimpulan mengenai tipe-tipe pewarta Injil atau misionaris. Sekurang-kurangnya ada dua tipe, 1) misionaris sebagai "tukang" baptis, dan 2) misionaris sebagai saksi Kristus tanpa harus melakukan pembaptisan.

Contoh tipe pertama. Pada zaman para rasul bisa kita jumpai dalam diri Santo Petrus. Kisah Para Rasul melaporkan jumlah orang yang dibaptis setelah mendengarkan pengajaran Petrus. Kira-kira ada sekitar tiga ribu orang yang memberikan dirinya dibaptis (bdk. Kis. 2:41). Setelah Petrus, dikisahkan juga bahwa Filipus melakukan pembaptisan atas orang-orang yang percaya kepada ajarannya, baik laki-laki maupun perempuan (bdk. Kis. 8:12).

Di Indonesia, pada tahun 1990, tercatat jumlah seluruh umat Katolik, yaitu sekitar 4.640.717 jiwa. $^{5}$ Salah satu faktor yang mempengaruhi jumlah umat Katolik di atas adalah karena adanya baptisan baru sebanyak $62 \%$. Selebihnya, $2 \%$ berasal dari mereka yang pindah dari gereja-gereja Kristen dan diterima di dalam gereja Katolik. Sisanya, yakni 36\% merupakan imigran dari tempat lain. Jumlah prosentase baptisan di atas, juga di tahun-tahun sebelumnya yang cenderung meningkat, menunjukkan bahwa fokus dan tujuan utama para misionaris awal ialah membaptis orang. ${ }^{6}$

Sedangkan contoh tipe kedua ialah Santo Paulus. Tidak banyak orang yang dibaptis oleh Paulus. Tercatat di dalam Kitab Suci, Paulus hanya membaptis dua orang saja plus keluarga Stefanus (bdk. 1Kor. 1:14-16). Alasan Paulus jelas, yaitu "Sebab Kristus mengutus aku bukan untuk membaptis, tetapi untuk memberitakan Injil; dan itupun bukan dengan hikmat perkataan, supaya salib Kristus jangan menjadi sia-sia" (1Kor. 1:17). Dalam konteks misi Indonesia, kita bisa menyebut di sini Franz van Lith. Pada 14 Desember 1904, ia membaptis 171 orang saja.

\footnotetext{
${ }^{5}$ H. J. W. M. Boelaars, Indonesianisasi. Dari Gereja Katolik di Indonesia Menjadi Gereja Katolik Indonesia, (Kanisius, Yogjakarta 2005), hlm. 191.

${ }^{6}$ Pada tahun 1975 ada 129.268 baptisan; 1980 berjumlah 160.136; 1985 berjumlah 163.229, dan pada tahun 1989 berjumlah 141.065 jiwa.
} 
Dibandingkan dengan jumlah baptisan yang dilakukan oleh Petrus, jumlah ini sangatlah sedikit. Selebihnya, Van Lith lebih banyak berkarya di bidang pendidikan dengan mendirikan sekolah-sekolah bagi orang Jawa, baik yang beragama Islam maupun Katolik. Tindakan van Lith ini merupakan bukti bahwa keselamatan berlaku bagi semua orang tanpa membeda-bedakan latar belakang agama, suku, dll.

Baptisan, dengan demikian, tidak bisa kita jadikan tolok ukur berhasil tidaknya sebuah misi. Meskipun van Lith membaptis sedikit orang, tetapi ia berhasil mengkader para (calon) pewarta kabar baik. Di antara para kadernya ialah Mgr. Soegijapranata dan I.J. Kasimo. Keduanya, di kemudian hari diangkat sebagai pahlawan nasional berkat perjuangan mereka untuk memerdekakan bangsa Indonesia dari penjajahan Belanda.

Selain persekolahan, para misionaris awal juga memikirkan bentuk-bentuk pewartaan kabar baik lainnya. Pelayanan-pelayanan yang dimulai dan dikembangkan di Indonesia ialah pelayanan kepada orang sakit, pelayanan kepada para petani dan nelayan kecil, pelayanan kepada para transmigran, pelayanan kepada kaum buruh, pelayanan kepada anakanak jalanan dan yang terpinggirkan, dll. Sedangkan Gereja dibangun ketika masyarakat sudah mulai menerima pewartaan keselamatan dan rahmat penebusan.

Logika ini mau mengatakan bahwa, seperti Rasul Paulus, para pewarta/misionaris, pertama-tama diutus bukan untuk membaptis orang, melainkan untuk mewartakan Injil yaitu kabar sukacita karena Allah senantiasa beserta kita (Imanuel) dan keselamatan yang ditawarkan oleh Allah bagi umat manusia.

\section{Penutup}

Yesus, dengan mengutus para muridNya untuk mewartakan Injil ke semua bangsa, sadar bahwa para murid akan bersinggungan dengan budaya lain, yang kerap sangat asing bagi mereka. Yesus sendiri sudah memberikan contoh bagaimana Ia berdialog dengan orang asing, dalam hal ini dengan perempuan Samaria. Dialog Yesus membuka hati dan pikiran perempuan Samaria bahwa kabar sukacita Injil itu telah datang 
yaitu Penyelamat Dunia, Sang Mesias, Yesus sendiri. Pada akhirnya, bukan hanya perempuan itu saja yang diselamatkan, melainkan juga seluruh penduduk kota. Tindakan Yesus ini mau mengatakan bahwa keselamatan itu bukan hanya eksklusif milik umat terpilih, melainkan juga diberikan bagi bangsa non Yahudi.

Para misionaris, sebagai yang diutus, juga memiliki tugas yang sama. Mereka diutus untuk mewartakan Injil Keselamatan Allah. Keselamatan Allah terbuka bagi semua bangsa, seluruh makhluk di dunia ini. Kreativitas dari pihak misionaris sungguh diminta, agar warta keselamatan itu sampai kepada semua orang dari semua bangsa. Kreativitas terwujud dan terukur dari bentuk-bentuk pelayanan yang dibangun dan dilakukan oleh mereka.

$====0000====$ 


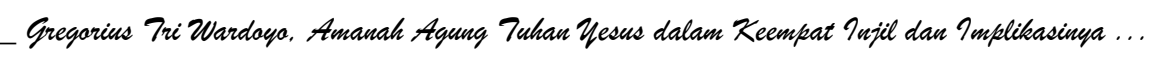

\section{DAFTAR PUSTAKA}

Alkitab Deuterokanonika, Jakarta: Lembaga Alkitab Indonesia, 2018.

Boelaars, H. J. W. M., Indonesianisasi. Dari Gereja Katolik di Indonesia Menjadi Gereja Katolik Indonesia, Yogjakarta: Kanisius, 2005.

Dokumen Konsili Vatikan II (terjemahan oleh R. Hardawiryana, S.J.), Dokumentasi dan Penerangan KWI, Jakarta: Obor, 1993.

Heuken, A., SJ, Ensiklopedi Orang Kudus. 1700 Nama Orang Kudus, Jakarta: Yayasan Cipta Loka Caraka, 2004.

Kirchberger, G.-Prior, J. M.-Julei, W., Teologi Misi di Kawasan Asia Pasifik, Ende: Nusa Indah, 1995.

Nestle-Aland, Novum Testamentum Graece, $28^{\text {th }}$ Revised Edition, Stuttgart: Deutsche Bibelgesellschaft, 2012.

Paus Benediktus XVI (terj. Emanuel P. D. Martasudjita, Pr.), The Apostles. Para Rasul. Asal-usul Gereja dan Para Teman Sekerja Mereka, Yogyakarta: Kanisius, 2015.

Perfezione evangelica. Tutto il pensiero di sanVincenzo de' Paoli esposto con le sue parole (a cura di un prete della missione), Roma: C.L.V. Edizione Vincenziane, 1990.

Ponticelli, S., CM.-Riyanto, A., CM., Sahabat-sahabat Tuhan dan Orang Miskin, Surabaya-Kediri: CM dan PK, 2002.

Poppy, A., Sinossi e commento. Esegetico-spirituale dei quattro vangeli, Padova: Edizioni Messagero, 2012.

Ratio Missionum. Vencentiana-46 ${ }^{\text {th }}$ year. Vol. 1, Januari-February 2002. 